\title{
The Virgin of Guadalupe
}

and the Conversos 


\section{LATINIDAD}

Transnational Cultures in the United States

This series publishes books that deepen and expand our knowledge and understanding of the various Latina/o populations in the United States in the context of their transnational relationships with cultures of the broader Americas. The focus is on the history and analysis of Latino cultural systems and practices in national and transnational spheres of influence from the nineteenth century to the present. The series is open to scholarship in political science, economics, anthropology, linguistics, history, cinema and television, literary and cultural studies, and popular culture and encourages interdisciplinary approaches, methods, and theories. The series grew out of discussions with faculty at the School of Transborder Studies at Arizona State University, where an interdisciplinary emphasis is being placed on transborder and transnational dynamics.

Matthew Garcia, Series Editor, School of Historical, Philosophical, and Religious Studies; and Director of Comparative Border Studies

For a list of titles in the series, see the last page of the book. 


\section{The Virgin of Guadalupe and the Conversos}

\section{Uncovering Hidden Influences \\ from Spain to Mexico}

MARIE-THERESA HERNÁNDEZ 
Library of Congress Cataloging-in-Publication Data

Hernández, Marie-Theresa, 1952- author

The virgin of Guadalupe and the conversos : uncovering hidden influences from Spain to Mexico / Marie-Theresa Hernandez

p. cm.-(Latinidad: Transnational Cultures in the United States)

Includes bibliographical references and index

ISBN 978-0-8135-6569-9 (hardcover : alk. paper) — ISBN 978-o-8135-6568-2 (pbk.) ISBN 978-0-8135-6570-5 (e-book)

I. Christianity and other religions-Judaism. 2. Judaism-Relations-Christianity. 3.

Crypto-Jews-Mexico-History-18th century. 4. Crypto-Jews-Mexico-HistoryI9th century. 5. Espinosa de los Monteros, Manuel, 1773-1838. 6. Carvajal, Luis de, I567?1596. 7. Guadalupe, Our Lady of. I. Title.

$\mathrm{BM}_{535} \cdot \mathrm{h}_{45} 82014$

261.2'60972-DC23

2013040662

A British Cataloging-in-Publication record for this book is available from the British Library.

Copyright $\odot 2014$ by Marie-Theresa Hernández

All rights reserved

No part of this book may be reproduced or utilized in any form or by any means, electronic or mechanical, or by any information storage and retrieval system, without written permission from the publisher. Please contact Rutgers University Press, I06 Somerset Street, New Brunswick, NJ 0890I. The only exception to this prohibition is "fair use" as defined by U.S. copyright law.

Visit our website: http://rutgerspress.rutgers.edu

Manufactured in the United States of America 
In Memory of John S. Broussard, C.S.B., 1919-2012 
